\title{
Identifikasi Cendawan Patogen pada Beberapa Kultivar Benih Kacang Tunggak (Vigna unguicullata L.) Berdasarkan Ketinggian Tempat yang Berbeda di Kabupaten Timor Tengah Utara
}

\author{
Elisabeth Buik Monemnasi ${ }^{\mathrm{a}}$ \\ ${ }^{a}$ Fakultas Pertanian, Universitas Timor, Kefamenanu, TTU - NTT, Indonesia, email: elisabethmonemnasi@ gmail.com
}

\section{Article Info}

\section{Article history:}

Received 14 Desember 2019

Received in revised form 22 Desember 2019 Accepted 27 Januari 2020

DOI:

https://doi.org/10.32938/sc.v4i01.924

\section{Keywords:}

Aspergillus sp

Altenaria $\mathrm{sp}$

Cendawan patogen

Collectotrichum sp

Fussarium $\mathrm{sp}$

Kacang tunggak

Ketinggian tempat

Melanospora sp.

\begin{abstract}
Abstrak
Tanaman kacang tunggak (Vigna unguiculata L.) merupakan salah satu tanaman leguminose. Secara fisiologis, tanaman ini memiliki tingkat adaptasi yang cukup tinggi, baik didataran rendah maupun tinggi sehingga menjadi tradisi bagi masyarakat Timor Tengah Utara (TTU) untuk terus membudidayakannya. Hasil produksi kacang tunggak di daerah TTU setiap tahun tetap saja rendah oleh karena kondisi lingkungan dan serangan cendawan patogen pada proses penyimpanan yang kurang tepat. Penelitian ini bertujuan untuk mengetahui jenis-jenis cendawan patogen yang menyerang, ketahanan Kultivar dan pengaruh ketinggian tempat terhadap aktivitas patogen. Penelitian ini dilaksanakan pada bulan September sampai Oktober 2019 di Laboratorium Fakultas Pertanian dan Laboratorium Biologi Universitas Timor. Rancangan penelitian menggunakan Rancangan Acak Lengkap (RAL) dengan 2 pola faktorial, faktor pertama Kultivar benih dan faktor kedua adalah daerah. Setiap perlakuan diulang sebanyak 3 kali sehingga terdapat 27 satuan percobaan. Pengamatan identifikasi patogen dilakukan dengan karakterisasi morfologi, dan pengujian vigor viabilitas benih dilakukan dengan metode UKDdp. Data hasil pengamatan kemudian dianalisis dengan menggunakan sidik ragam (anova) rancangan acak lengkap (RAL) dan diuji lanjut dengan menggunakan Duncan Multiple Range Test (DMRT) dengan tingkat signifikan $5 \%$. Berdasarkan penelitian yang telah dilaksanakan, bahwa terdapat lima cendawan kontamin yang mengkontaminasi benih kacang tunggak Kultivar merah, putih, hitam dari beberapa daerah di wilayah TTU antara lain Cendawan Fussarium sp, Cendawan Melanospora sp, Cendawan Collectotrichum sp, Cendawan Aspergillus sp, dan Cendawan Altenaria sp. Serangan terbesar disebabkan oleh cendawan Fussarium sp.
\end{abstract}

\section{Pendahuluan}

Kacang tunggak (Vigna unguiculata L.) merupakan salah satu tanaman yangkeberadaannya sudah lama diketahui bahkan sudah dibudidayakan diseluruh dunia termasuk Indonesia. Kacang tunggak dikategorikan sebagai tanaman leguminose dengan tingkat gizi lemak yang cukup tinggi. Kandungan protein yang terdapat pada kacang tunggak yaitu 22,9 gr/100 gr. Selain itu, kacang tunggak juga mengandung lisin yang cukup tinggi sehingga menyempurnakan kualitas potein biji-bijian dan berpotensi sebagai sumber protein nabati (Sadikin Somaatmadja, 1990). Di daerah Timor Tengah Utara (TTU) tanaman ini umumnya dikenal sebagai tanaman melilit sehingga disebut kacang tali. Kacang tunggak atau kacang tali biasanya ditanam secara tumpang sari. Hal ini dikarenakan kacang tunggak termasuk tanaman yang bersifat alih fungsi sehingga dapat dimanfaatkan sebagai bahan pangan, bahan baku industri maupun bahan pakan (Inaizumi et al., 1999). Tingkat adaptasi pada berbagai kondisi lingkungan cukup tinggi maka menjadi tradisi bagi masyarakat Timor terutama masyarakat TTU untuk terus membudidayakan kacang tunggak secara tumpang sari dengan tanaman pangan lain seperti jagung.

Kacang tunggak mampu beradaptasi pada berbagai kondisi lingkungan, baik itu di dataran tinggi seperti Kecamatan Miomaffo Barat (Eban), dataran menengah seperti Noemuti (Korea) maupun didataran rendah seperti Insana Utara (Wini) namun hasil produksi kacang tunggak masih saja rendah. Hal itu dikarenakan adanya beberapa faktor yang mungkin menjadi faktor penghambat. Faktor-faktor yang menjadi penyebab rendahnya hasil produksi berupa faktor eksternal dan internal (Kamil, 1982). Faktor eksternal berupa faktor yang berkaitan dengan keadaan lingkungan seperti suhu, udara, kelembapan, cahaya, sedangkan faktor internal berupa kultivar benih atau kondisi benih seperti kebersihan, vigor, kadar air, dan tingkat kerusakan mekanis.

Sistem budidaya yang perlu diperhatikan adalah vigor benih atau kesehatan benih. Salah satu faktor rendahnya hasil produksi adalah kualitas benih. Perlakuan benih yang dilakukan masyarakat TTU usai panen adalah disimpan dalam jerigen, karung, drum, dan diberi pengasapan didapur dengan tujuan menghindari adanya serangan patogen yang merugikan. Kenyataannya model penyimpanan ini tidak menjamin kesehatan benih. Penyakit terbawa benih saat panen adalah salah satu faktor penghambat yang juga merupakan penyebab rendahya hasil produksi dan kualitas benih. Penyakit ini disebabkan oleh serangan cendawan patogen, oleh karena patogen dapat hidup lebih lama didalam benih jenis kacang-kacangan termasuk kacang tunggak sebagai parasit dengan menggunakan nutrisi didalam benih untuk mempertahankan hidupnya. Penyakit terbawa benih juga disebabkan oleh kurang efisiennya proses pasca panen sehingga menyebabkan adanya serangan cendawan patogen dan dapat mengurangi nilai gizi sekaligus dapat merusak kualitas biji. Menurut Sutopo (2004), benih yang bermutu dapat dilihat dari mutu genetis yang berkaitan dengan kemurniaan kultivar, mutu fisiologi berdasarkan daya kecambah dan vigor yang baik serta mutu fisik. Mutu fisik dapat dilihat dari bentuk luar seperti ukuran yang homogen, sehat yang artinya bebas dari infeksi dan kontaminasi patogen serta bebas hama penyakit. Secara visual kesehatan benih ditentukan oleh ada tidaknya mikroorganisme terbawa benih seperti jamur, patogen, nematoda, virus, dan bakteri (Misra et al., 1994).

Selain kultivar benih yang rentan terhadap penyakit, kondisi lingkungan juga menjadi faktor keberadaan patogen, misalkan ketinggian tempat. Berdasarkan tata letak wilayah TTU, Kecamatan Miomaffo Barat, Kecamatan Noemuti dan Kecamatan Insana Utara mempunyai ketinggian tempat yang berbeda-beda. Ketinggian tempat mempunyai kelembapan yang cukup baik. Kelembaban yang tinggi membuat ketahanan tubuh patogen lebih kuat dan lebih mudah menginfeksi aneka benih kacang. Menurut Abadi (2003) kondisi lingkungan dengan tingkat kelembapan yang tinggi sangat berpengaruh dengan adanya patogen, karena meningkatkan sporulasi cendawan, pelepasan spora, dan perbanyakan bakteri. Selain itu pengaruh suhu terhadap patogen seperti perkecambahan spora, penetrasi inang, pertumbuhan dan reproduksi patogen, invasi inang, dan sporulasi.

Penanganan yang perlu diperhatikan untuk meningkatkan hasil produksi kacang tunggak adalah dengan mengadakan pengujian kesehatan benih Pengujian kesehatan benih merupakan suatu tindakan untuk memastikan ada tidaknya mikroorganisme patogenik yang menjadi penyebab kerusakan benih atau terkontaminasinya benih dengan cendawan patogen selama penyimpanan. Pengujian benih dilakukan dengan cara mengidentifikasi jenis patogen yang menyerang sehingga memudahkan dalam proses pengendalian. Timor Tengah Utara merupakan salah satu daerah dengan potensi budidaya kacang tunggak yang tinggi secara tumpang sari, akan tetapi hingga saat ini belum adanya identifikasi secara khusus mengenai jenis cendawan yang menyebabkan pertumbuhan dan perkembangan tanaman kacang tunggak terganggu sehingga sangat penting untuk melakukan identifikasi untuk mengetahui keberadaan cendawan patogen terbawa benih kacang tunggak pada Kecamatan Miomaffo Barat, Kecamatan Noemuti, dan Kecamatan Insana Utara. Penelitian ini bertujuan untuk mengetahui jenis-jenis cendawan patogen yang menyerang benih kacang tunggak, mengetahui ketahanan kultivar kacang tunggak dari serangan patogen, dan mengetahui pengaruh ketinggian tempat terhadap aktivitas patogen.

\section{Metode}

Penelitian ini dilaksanakan pada bulan September-Oktober 2019 di Laboratorium Fakultas Pertanian Universitas Timor dan Laboratorium Program Studi Biologi, Kota Kefamenanu Kabupaten Timor Tengah Utara (TTU) Provinsi Nusa Tenggara Timur (NTT). Dengan lokasi pengambilan sampel di Kecamatan Noemuti (korea) dengan ketinggian tempat 500-700 mdpl, Kecamatan Insana Utara (Wini) dengan ketinggian tempat antara 100-200 mdpl, dan Kecamatan Miomaffo Barat (Eban) dengan ketinggian tempat sekitar 2.270 mdpl. Penelitian ini menggunakan rancangan acak lengkap dengan 2 pola faktorial. Faktor 1 adalah benih kacang tunggak kultivar lokal yang terdiri dari 3 aras yaitu $\mathrm{V}_{1}$ : kultivar lokal merah, $\mathrm{V}_{2}$ : kultivar lokal putih, dan $\mathrm{V}_{3}$ : kultivar lokal hitam. Faktor 2 yaitu ketinggian tempat yang terdiri dari 3 aras yaitu $D_{1}$ : Kecamatan Noemuti (Korea), $\mathrm{D}_{2}$ : Kecamatan Insana Utara (Wini), $\mathrm{D}_{3}$ : Kecamatan Miomaffo Barat (Eban). Kombinasi perlakuannya adalah $\mathrm{D}_{1} \mathrm{~V}_{1}$, $D_{2} V_{1}, D_{3} V_{1}, D_{1} V_{2}, D_{2} V_{2}, D_{3} V_{2}, D_{1} V_{3}, D_{2} V_{3}, D_{3} V_{3}$, Sehingga terdapat 9 kombinasi perlakuan dan diulang sebanyak 3 kali maka secara keseluruhan menjadi 27 satuan percobaan. Perlakuan yang berbeda nyata dilanjutkan dengan uji DMRT (Duncan Multiple Range Test).

Benih yang digunakan dalam penelitian ini adalah benih kacang tunggak yang diambil dari tiga daerah berbeda yaitu Noemuti, Wini, dan Eban. Benih dengan pilihan identitas berkualitas tinggi dan secara kasat mata, benih yang diambil harus benar-benar bebas hama penyakit (sehat) dan terlihat bersih. Pengamatan dilakukan dengan mengamati beberapa karakter morfologi secara makroskopis dan mikroskopis. Secara makroskopis cendawan diamati berdasarkan warna koloni dan bentuk sedangkan secara mikroskopis dilakukan dengan teknik pemurnian (Ningsih et al., 2012). Parameter yang diamati adalah sebagai berikut:

\section{Potensi Tumbuh Maksimum (\%)}

Potensi tumbuh maksimum diperoleh dengan menghitung jumlah kecambah yang tumbuh normal dan abnormal pada hari ke-7 setelah tanam 
(hst). Potensi tumbuh maksimum dapat dihitung dengan rumus sebagai berikut :

$$
\text { PTM }=\frac{\text { Jumlah benih yang tumbuh }}{\text { Jumlah benih yang ditanam }} \times 100 \%
$$

\section{Daya Berkecambah (\%)}

Daya berkecambah diperoleh dengan menghitung kecambah yang tumbuh normal pada hari ke-1 (5hst) dan hari ke-2 (7hst).Daya berkecambah dihitung dengan rumus:

$$
D B=\frac{\text { Jumlah benih yang berkecambah normal }}{\text { Jumlah benih yang ditanam }} \times 100 \%
$$

\section{Indeks Vigor (\%)}

Indeks vigor dihitung berdasarkan persentase jumlah kecambah normal pada hitungan pertama (first count) (7 HST) di bagi dengan jumlah benih yang ditanam. Indeks vigor dihitung dengan rumus:

$$
\operatorname{IV}(\%)=\frac{\Sigma \text { Kecambah normal pada hitungan pertama }}{\Sigma \text { Benih yang ditanam }} \times 100 \%
$$

\section{Identifikasi Patogen dan Kejadian Penyakit Berdasarkan Jenis}

Patogen

Karakter morfologi cendawan akan diidentifikasi dengan menumbuhkan isolat cendawan pada media agar PDA sesuai genus, diinkubasi selama beberapa hari, selanjutnya diamati dengan mikroskop. Isolat cendawan ditumbuhkan pada media PDA untuk pengamatan karakter koloni. Identifikasi patogen menggunakan buku identifikasi Putterill (1954), Manamgoda et al., (2014), Parmeter (1970), Roberts (1999) dan Toda (2007). Presentase kejadian penyakit dihitung dengan menggunakan rumus:

$$
\mathrm{P}=\frac{A}{B} X 100 \%
$$

Keterangan: $P=$ Presentase benih yang ditumbuhi cendawan $A, A=$ Jumlah benih yang ditumbuhi cendawan, $B=$ jumlah benih yang diamati (sampel)

5. Kejadian Penyakit Secara Umum erikut:

Presentase kejadian penyakit dapat dihitung dengan rumus sebagai

$$
\mathrm{KP}=\frac{n}{N} X 100 \%
$$

Keterangan: $K P=$ Kejadian penyakit, $N=$ Jumlah tanaman yang diamati disetiap perlakuan, $n=$ Jumlah benih yang terserang patogen

Data hasil pengamatan kemudian dianalisis dengan menggunakan sidik ragam (anova) rancangan acak lengkap (RAL). Rata-rata perlakuan dapat diuji lanjut dengan menggunakan Duncan Multiple Range Test (DMRT) dengan tingkat signifikan 5\% sesuai petunjuk Gomes dan Gomes (1995). Analisis data menggunakan program SAS 9.1.

\section{Hasil dan Pembahasan \\ 3.1. Hasil}

\section{Potensi Tumbuh Maksimum}

Potensi tumbuh maksimum merupakan salah satu parameter pengujian viabilitas benih (Sutopo, 2004) berupa daya hidup benih yang ditunjukkan melalui sifat fisiologis maupun biokimia dalam mengetahui laju pertumbuhan benih (Sadjad, 1994). Uji benih maupun daya kecambah dapat ditunjukkan melalui kemampuan benih dalam memberikan hasil terbaik dalam hal ini kecepatan tumbuh normal maupun abnormal (Gambar 1).

Gambar 1. Karakteristik benih normal-abnormal
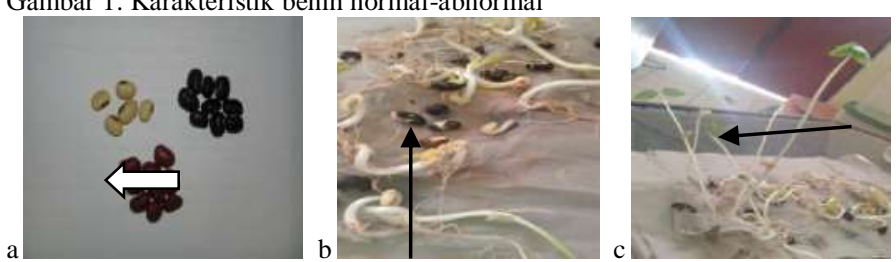

Keterangan : a) Benih sebelum diadakan perlakuan, b) Kecambah abnormal, c) Kecambah normal.

Berdasarkan hasil sidik ragam anova menunjukkan tidak terjadi interaksi antara kultivar benih dengan ketinggian tempat dari ketiga daerah pada parameter pengamatan potensi tumbuh maksimum. kultivar kacang tunggak berwarna hitam (V3) menunjukkan nilai tertinggi yaitu 92,44\% dan pada daerah Wini $89,78 \%$, tidak berbeda nyata dengan perlakuan lainnya (Tabel 1).

\section{Daya Kecambah}

Berdasarkan hasil sidik ragam anova menunjukkan bahwa terjadi interaksi antara Kultivar benih dan ketinggian tempat dari ketiga daerah pada parameter pengamatan daya berkecambah. Kultivar benih kacang tunggak putih (V2) pada daerah Noemuti (D1) memberikan nilai terbaik dengan prosentase $94,67 \%$, berbeda nyata dengan perlakuan lainnya (Tabel 2). $\underline{\text { Tabel 1. Potensi Tumbuh Maksimum }}$

\begin{tabular}{ccccc}
\hline \multirow{2}{*}{ Kultivar } & \multicolumn{3}{c}{ Daerah } & \multirow{2}{*}{ Rerata } \\
\cline { 2 - 4 } & Noemuti (D1) & Wini (D2) & Eban (D3) & \\
\hline Merah (V1) & 82.67 & 84.00 & 65.33 & $77.33^{\mathrm{b}}$ \\
Putih (V2) & 85.33 & 86.67 & 78.67 & $83.56^{\mathrm{ab}}$ \\
Hitam (V3) & 89.33 & 98.67 & 89.33 & $92.44^{\mathrm{a}}$ \\
\hline Rerata & $85.78^{\mathrm{ab}}$ & $89.78^{\mathrm{a}}$ & $77.78^{\mathrm{b}}$ & $(-)$ \\
\hline Keterangan : Angka pada baris dan kolom diikuti dengan huruf yang sama tidak berbeda
\end{tabular}

Keterangan : Angka pada baris dan kolom diikuti dengan huruf yang sama tidak berbeda nyata menurut uji duncan 5\%.(-): Tidakterjadi interaksi antar faktor.

Tabel 2. Daya Berkecambah

\begin{tabular}{ccccc}
\hline \multirow{2}{*}{ Kultivar } & \multicolumn{3}{c}{ Daerah } & \multirow{2}{*}{ Rerata } \\
\cline { 2 - 4 } & Noemuti (D1) & Wini (D2) & Eban (D3) & \\
\hline Merah (V1) & $84.00^{\mathrm{bc}}$ & $89.33^{\mathrm{ab}}$ & $77.33^{\mathrm{c}}$ & 83.56 \\
Putih (V2) & $94.67^{\mathrm{a}}$ & $82.67^{\mathrm{bc}}$ & $76^{\mathrm{c}}$ & 84.44 \\
Hitam (V3) & $85.33^{\mathrm{abc}}$ & $84^{\mathrm{bc}}$ & $84^{\mathrm{bc}}$ & 84.44 \\
\hline Rerata & 88.00 & 85.33 & 79.11 & $(+)$ \\
\hline
\end{tabular}

Keterangan : Angka pada baris dan kolom diikuti dengan huruf yang sama berbeda nyata menurut uji duncan $5 \% .(+)$ : Terjadi interaksi antar faktor.

\section{Indek Vigor}

Berdasarkan hasil sidik ragam anova menunjukkan bahwa tidak terjadi interaksi antara Kultivar benih dan ketinggian tempat dari ketiga daerah pada parameter pengamatan indeks vigor. Kultivar benih kacang tunggak merah (V1) memberikan nilai tertinggi dengan prosentase 90,67 \% dan pada daerah Noemuti $88,89 \%$, tidak berbeda nyata dengan perlakuan lainnya (Tabel 3).

Tabel 3. Indeks Vigor

\begin{tabular}{ccccc}
\hline \multirow{2}{*}{ Kultivar } & \multicolumn{3}{c}{ Daerah } & \multirow{2}{*}{ Rerata } \\
\cline { 2 - 4 } & Noemuti (D1) & Wini (D2) & Eban (D3) & \\
\hline Merah (V1) & 90.67 & 94.67 & 86.67 & $90.67^{\text {aa }}$ \\
Putih (V2) & 85.33 & 89.33 & 88 & $87.56^{\text {aa }}$ \\
Hitam (V3) & 90.67 & 77.33 & 77.33 & $81.78^{\text {a }}$ \\
\hline Rerata & $88.89^{\text {aa }}$ & $87.11^{\text {aa }}$ & $84.00^{\text {a }}$ & $(-)$ \\
\hline Keterangan : Angka pada baris dan kolom diikuti dengan huruf yang sama tidak berbeda
\end{tabular}
nyata menurut uji duncan 5\%.(-): Tidak terjadi interaksi antar faktor.

\section{Identifikasi Patogen dan Kejadian Penyakit Berdasarkan Jenis Patogen} Cendawan Fussarium sp.

Berdasarkan hasil pengamatan secara makroskopis cendawan Fussariium sp. memiki ciri awal berwarna putih dan mengalami perubahan warna kemerahan setelah berumur 4-5 hari, pertumbuhan tidak merata, berserat halus dan berkembang sangat cepat pada media PDA. Cendawan memenuhi cawan petri pada hari ke 7. Secara mikroskopis cendawan Fussariium sp. mempunyai hifa bersekat, bentuk sporanya melengkung agak panjang, bersekat dan ujung meruncing.Rusae, at all (2015) menyatakan bahwa gejala yang disebabkan cendawan Fussarium sp. adalah busuk pucuk dengan ciri-ciri bentuk konidia oval, terdiri dari septa berwarna hialin dan bagian tengah membesar. Berdasarkan penelitian Nugraheni (2010) bahwa cendawan Fussarium sp. memiliki makrokonidia berbentuk melengkung, panjang dengan ujung yang mengecil dan bersekat Adapun ciri-ciri dari fussarium sp yaitu warna koloni berwarna hitam kemerahan dengan struktur tubuh berupa miselium bercabang, hialin, dan bersekat (septat). Konidia terdiri dari 3 atau 4 sekat berwarna hialin, bagian tengahnya membesar sehingga kedua ujung konidia berbentuk meruncing seperti bulan sabit.

Cendawan fussarium sp adalah salah satu jenis cendawan gudang yang memilki kemampuan untuk menginfeksi benih pada waktu penyimpanan (Justice \& Bass, 2002) sehingga menyebabkan penyakit saat persemaian atau tanaman dewasa di lapangan. Selama masa penyimpanan benih, aktivitas cendawanpun terhenti (Rahayu, 1999).Berdasarkan ciri-ciri tersebut dapat dilihat pada (Gambar 2).

\section{Gambar 2.Karakteristik Cendawan Fussarium sp.}

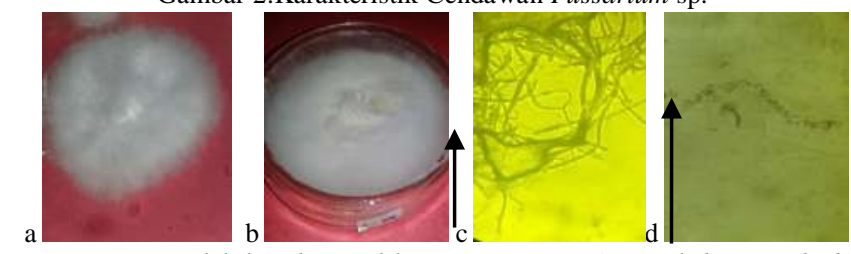

Keterangan: Bentuk koloni dan morfologi Fussarium sp. a) tampak depan muda, $b$ tampak depan tua, c) hifa, d) konidia.

Hasil sidik ragam anova menunjukkan bahwa terjadi interaksi antara daerah dengan Kultivar pada parameter pengamatan patogen fussarium $s p$. Daerah Wini (D2) Kultivar putih dan hitam, dan Eban Kultivar kacang tunggak merah dan hitam memberikan nilai yang terbaik dengan prosentase terendah 0,00\% (Tabel 4). 
Tabel 4. Cendawan Fussarium sp.

\begin{tabular}{ccccc}
\hline \multirow{2}{*}{ Kultivar } & \multicolumn{3}{c}{ Daerah } & \multirow{2}{*}{ Rerata } \\
\cline { 2 - 4 } & Noemuti (D1) & Wini (D2) & Eban (D3) & \\
\hline Merah (V1) & $66.67^{\mathrm{ab}}$ & $10.00^{\mathrm{c}}$ & $0.00^{\mathrm{c}}$ & 25.56 \\
Putih (V2) & $33.33^{\mathrm{bc}}$ & $0.00^{\mathrm{c}}$ & $60.00^{\mathrm{ab}}$ & 31.11 \\
Hitam (V3) & $86.67^{\mathrm{a}}$ & $0.00^{\mathrm{c}}$ & $0.00^{\mathrm{c}}$ & 28.89 \\
\hline Rerata & 62.22 & 3.33 & 20.00 & $(+)$ \\
\hline
\end{tabular}

Keterangan : Angka pada baris dan kolom diikuti dengan huruf yang sama berbeda nyata menurut uji duncan 5\%.(+): Terjadi interaksi antar faktor.

\section{Cendawan Melanospora sp.}

Berdasarkan karakteristik morfologi cendawan Melanospora sp. secara makroskopis koloni dari cendawan ini berwarna putih kehitaman, tampak miselium berstruktur halus dan pertumbuhannya kesamping memenuhi cawan petri secara merata pada hari ke 7, Sedangkan secara mikroskopis memperlihatkan spora berbentuk bulat kasar, konidiofor berdinding halus, berwarna coklat, untuk lebih jelasnya dapat dilihat pada (Gambar 3).

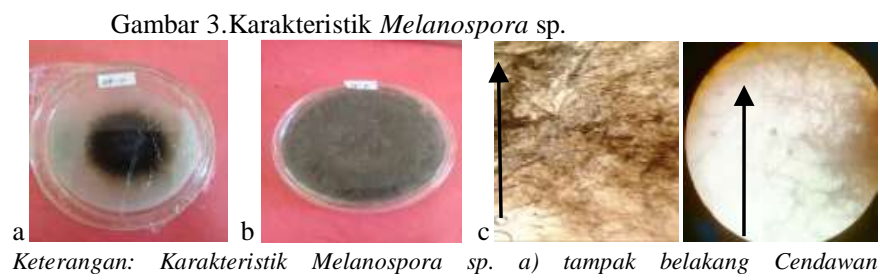
Melanospora sp. muda, b) tampak depan cendawan tua, c) spora/konidia

Tabel 5. Cendawan Melanospora sp.

\begin{tabular}{ccccc}
\hline \multirow{2}{*}{ Kultivar } & \multicolumn{3}{c}{ Daerah } & \multirow{2}{*}{ Rerata } \\
\cline { 2 - 4 } & Noemuti (D1) & Wini (D2) & Eban (D3) & \\
\hline Merah (V1) & $0.00^{\mathrm{d}}$ & $73.33^{\mathrm{ab}}$ & $40.00^{\mathrm{bcd}}$ & 37.78 \\
Putih (V2) & $60.00^{\mathrm{abc}}$ & $60.00^{\mathrm{abc}}$ & $26.67^{\mathrm{bcd}}$ & 48.89 \\
Hitam (V3) & $13.33^{\mathrm{cd}}$ & $93.33^{\mathrm{a}}$ & $0.00^{\mathrm{d}}$ & 35.56 \\
\hline Rerata & 24.44 & 75.56 & 22.22 & $(+)$ \\
\hline
\end{tabular}

Keterangan : Angka pada baris dan kolom diikuti dengan huruf yang sama berbeda nyata menurut uji duncan $5 \%$.(+): Terjadi interaksi antar faktor.

Hasil sidik ragam anova menunjukkan bahwa terjadi interaksi antara daerah dengan Kultivar pada parameter pengamatan melanospora sp. Daerah Noemuti (D1) Kultivar merah (V1) dan daerah Eban (D3) Kultivar hitam (V3) memberikan nilai yang terbaik dengan prosentase terendah $0,00 \%$, berbeda nyata dengan perlakuan lainnya (Tabel 5).

\section{Cendawan Collectotrichum sp.}

Secara makroskopis jamur Collectotrichum sp. memiliki miselium yang tumbuh pada media PDA berwarna putih, dan berstruktur halus. Pertumbuhan miselium kearah samping dan memenuhi cawan petridis dalam waktu 7 hari. Sedangkan secara mikroskopis konidia berbentuk silinder dengan ujung-ujung tumpul, adapula yang berbentuk agak jorong dan ujung agak membulat, tidak bersekat, warna spora agak kecoklatan (Gambar 4).

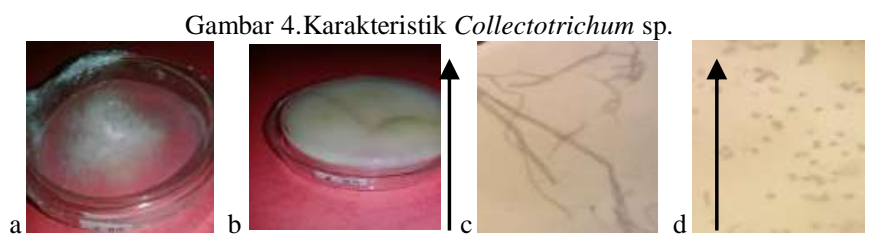

Keterangan: Karakteristik Cendawan Collectotrichum sp. a) Tampak depan, b) Tampak belakang, c) Hifa, d) Konidia.

Hal ini sesuai dengan pendapat Semangun (2000) bahwa jamur cendawan Collectotrichum sp. memiliki konidium hialin yang berbentuk agak jorong dengn ujung yang agak membulat dan pangkal agak sempit terpancung, tidak bersekat, berinti satu, panjang $9 \mathrm{~mm}-24 \times 3-6 \mathrm{~mm}$, terbentuk pada konidiofor berbentuk silinder dan hialin berwarna agak kecoklatan.

\section{Tabel 6. Cendawan Collectotrichum sp.}

\begin{tabular}{ccccc}
\hline \multirow{2}{*}{ Kultivar } & \multicolumn{3}{c}{ Daerah } & \multirow{2}{*}{ Rerata } \\
\cline { 2 - 4 } & Noemuti (D1) & Wini (D2) & Eban (D3) & \\
\hline Merah (V1) & 0.00 & 20.00 & 0.00 & $6.67^{\mathrm{a}}$ \\
Putih (V2) & 0.00 & 20.00 & 0.00 & $6.67^{\mathrm{a}}$ \\
Hitam (V3) & 0.00 & 0.00 & 0.00 & $0.00^{\mathrm{a}}$ \\
\hline Rerata & $0.00^{\mathrm{a}}$ & $13.33^{\mathrm{a}}$ & $0.00^{\mathrm{a}}$ & $(-)$ \\
\hline Keterangan
\end{tabular}
berbeda nyata menurut uji duncan 5\%.(-): Tidak terjadi interaksi antar faktor.

Hasil sidik ragam anova menunjukkan bahwa tidak terjadi interaksi antara daerah dengan Kultivar pada parameter pengamatan Collectotrichum sp. Semua perlakuan Kultivar di daerah Noemuti (D1) dan
Eban (D3) memberikan nilai yang terbaik dengan prosentase terendah $0,00 \%$, tidak berbeda nyata dengan perlakuan lainnya (Tabel 6).

\section{Cendawan Aspergillus sp.}

Berdasarkan hasil pegamatan secara makroskopis Cendawan Aspergillus sp. mempunyai beberapa ciri-ciri antara lain berwarna hitam keputih kuningan, dengan tepia rata, hifa bersekat. Konidiofor tegak, panjang, ujung konidia berwarna hitam membentuk bulatan telur dan berbentuk secara bebas (Gambar 5.) Cendawan Aspergillus sp. merupakan salah satu jenis cendawan gudang yang memberikan banyak kerugian dan banyak menyerang benih pada saat penyimpanan (Justice dan Bass, 2002). Menurut Sutjiati \& Saenong (2002) menyatakan bahwa fungi Aspergillus sp. pada biji-bijian yang disimpan dapat menyebabkan penurunan daya kecambah, perubahan warna, kenaikan suhu, dan kelembapan didalam benih serta perubahan susunan kimia didalam benih produksi dan akumulasi mitotoksin pada benih. Cendawan ini juga menginfeksi benih kacang tunggak.

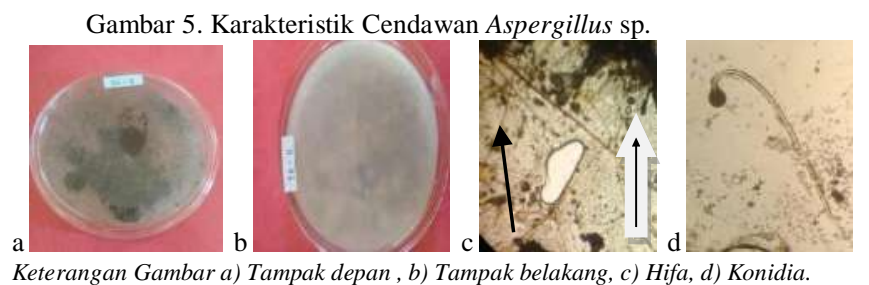

Tabel 7. Cendawan Aspergillus sp.

\begin{tabular}{ccccc}
\hline \multirow{2}{*}{ Kultivar } & \multicolumn{3}{c}{ Daerah } & \multirow{2}{*}{ Rerata } \\
\cline { 2 - 4 } & Noemuti (D1) & Wini (D2) & Eban (D3) & \\
\hline Merah (V1) & 0.00 & 6.67 & 60.00 & $22.22^{\mathrm{a}}$ \\
Putih (V2) & 0.00 & 20.00 & 6.67 & $8.89^{\mathrm{a}}$ \\
Hitam (V3) & 0.00 & 0.00 & 26.67 & $8.89^{\mathrm{a}}$ \\
\hline Rerata & $0.00^{\mathrm{b}}$ & $8.89^{\mathrm{b}}$ & $31.11^{\mathrm{a}}$ & $(-)$ \\
\hline Keterangan : Angka pada baris dan kolom diikuti dengan huruf yang sama tidak
\end{tabular}

berbeda nyata menurut uji duncan5\%.(-): Tidak terjadi interaksi antar faktor.

Hasil sidik ragam anova menunjukkan bahwa tidak terjadi interaksi antara daerah dengan kultivar pada parameter pengamatan Aspergillus sp. Daerah Noemuti (D1) dan kultivar kacang tunggak putih (V2) serta hitam (V3) memberikan nilai yang terbaik dengan prosentase terendah yaitu $0,00 \%$ dan $8,89 \%$, berbeda nyata antara daerah dan tidak berbeda nyata antara kultivar (Tabel 7)

\section{Cendawan Altenaria sp.}

Altenariasp. adalah miselium yang tumbuh pada medium PDA yang secara makroskopis memiliki karakter berwarna putih keabu-abuan dengan tepian hitam, arah pertumbuhan kesamping, struktur miselium kasar, dan secara mikroskopis cendawan Altenaria sp memiliki warna hifa agak gelap, konidiofor agak memanjang, dan konidia berbentuk seperti buah pear, terdiri dari 2-3 sel, gada terdiri dari banyak sel, berwarna agak kecoklatan (Gambar 6).

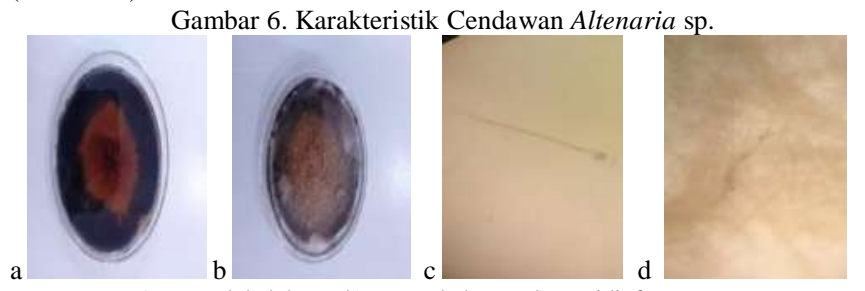

Keterangan: a) Tampak belakang, b) Tampak depan, d) Konidiofor

Tabel 8. Cendawan Altenaria sp.

\begin{tabular}{ccccc}
\hline \multirow{2}{*}{ Kultivar } & \multicolumn{3}{c}{ Daerah } & \multirow{2}{*}{ Rerata } \\
\cline { 2 - 4 } & Noemuti (D1) & Wini (D2) & Eban (D3) & \\
\hline Merah (V1) & $0.00^{\mathrm{b}}$ & $0.00^{\mathrm{b}}$ & $0.00^{\mathrm{b}}$ & 0.00 \\
Putih (V2) & $0.00^{\mathrm{b}}$ & $0.00^{\mathrm{b}}$ & $0.00^{\mathrm{b}}$ & 0.00 \\
Hitam (V3) & $0.00^{\mathrm{b}}$ & $0.00^{\mathrm{b}}$ & $73.33^{\mathrm{a}}$ & 24.44 \\
\hline Rerata & 0.00 & 0.00 & 24.44 & $(+)$ \\
\hline
\end{tabular}

Keterangan: Angka pada baris dan kolom diikuti dengan huruf yang sama berbeda nyata menurut uji duncan 5\%.(+): Terjadi interaksi antar faktor.

Hasil sidik ragam anova menunjukkan bahwa terjadi interaksi antara daerah dengan kultivar pada parameter pengamatan Altenaria sp. Daerah Noemuti (D1), Wini (D2), Eban (D3) dengan kultivar kacang tunggak merah (V1), putih (V2), hitam (V3) memberikan nilai yang terbaik dengan prosentase terendah yaitu $0,00 \%$ dan berbeda nyata dengan daerah Eban (D3) pada kultivar kacang tunggak hitam (V3) (Tabel 8) 


\section{Benih Terserang Secara Umum}

Hasil sidik ragam anova menunjukkan bahwa tidak terjadi interaksi antara daerah dengan Kultivar pada parameter pengamatan jumlah benih yang terserang penyakit. Daerah Noemuti (D1), dan Kultivar kacang tunggak putih (V2) memberikan nilai yang terbaik dengan prosentase terendah yaitu 95,56\% dan 93,33\% serta tidak berbeda nyata antara daerah dan kultivar (Tabel 9)

Tabel 9. Jumlah yang Terserang Secara Umum

\begin{tabular}{ccccc}
\hline \multirow{2}{*}{ Kultivar } & \multicolumn{3}{c}{ Daerah } & \multirow{2}{*}{ Rerata } \\
\cline { 2 - 4 } & Noemuti (D1) & Wini (D2) & Eban (D3) \\
\hline Merah (V1) & 100.00 & 100.00 & 100.00 & $100.00^{\mathrm{a}}$ \\
Putih (V2) & 86.67 & 100.00 & 93.33 & $93.33^{\mathrm{a}}$ \\
Hitam (V3) & 100.00 & 93.33 & 100.00 & $97.78^{\mathrm{a}}$ \\
\hline Rerata & $95.56^{\mathrm{a}}$ & $97.78^{\mathrm{a}}$ & $97.78^{\mathrm{a}}$ & $(-)$ \\
\hline Keterangan : Angka pada baris dan kolom diikuti dengan huruf yang sama tidak
\end{tabular}

berbeda nyata menurut uji duncan 5\%.(-): Tidak terjadi interaksi antar faktor.

\subsection{Pembahasan}

Ketinggian tempat menjadi peluang besar bagi cendawan untuk berkembang biak karena bersifat lembab. Semakin rendah ketinggian tempat suatu daerah memberikan hasil yang baik karena berpengaruh terhadap rendahnya kadar air. Kehidupan patogen tergantung pada kondisi lingkungan, suhu, iklim. Sehingga dari hasil pengamatan telah diketahui bahwa kadar air terendah dari daerah Wini (D2) Kultivar merah (V1) dengan ketinggian tempat 100-200 mdpl. Hal itu memungkinkan bahwa tingkat serangan patogen tertinggi terdapat benih kacang tunggak Kultivar merah 4,06 \% di daerah Eban dan Noemuti dengan ketinggian tempat dari masing - masing daerah 2.270 mdpl dan 500-700 mdpl.

Pengujian vigor dan viabilitas benih memberikan petunjuk mutu benih yang baik dalam berkecambah normal dan abnormal berupa daya hidup benih yang ditunjukkan melalui sifat fisiologis maupun biokimia dalam mengetahui laju pertumbuhan benih (Sadjad, 1994). Demikian juga pada pengamatan potensi tumbuh maksimum terhadap Kultivar benih dari ketiga daerah dengan ketinggian tempat yang berbeda telah diketahui bahwa benih kacang tunggak hitam dari daerah Wini memberikan hasil kecambah normal teringgi 92,44\% dan terendah dari daerah Eban Kultivar merah $77,33 \%$. Sedangkan untuk parameter daya berkecambah dari ketiga daerah adalah Noemuti Kultivar putih dan hitam 88,00 \%, terendah dari daerah Eban merah 79,11 \%. Pengamatan indeks vigor, hasil kecambah normal tertinggi terdapat pada benih dari daerah Noemuti Kultivar merah 88,89\% dan Eban adalah daerah dengan jumlah benih berkecambah terendah yaitu $84,00 \%$. Berdasarkan hasil identifikasi mikroskopis yang dilakukan pada Kultivar kacang tunggak dari beberapa daerah di TTU, telah diketahui bahwa ada 5 jenis cendawan yang menginfeksi (mengkontaminasi) benih kacang tunggak yaitu cendawan Fussarium sp., cendawan Melanospora sp., cendawan Collectotrichum sp., cendawan Aspergillus sp., cendawan Altenaria sp.Serangan cendawan fussarium $\mathrm{sp}$ tertinggi terdapat pada Kultivar kacang tunggak hitam dari Noemuti (500mdpl), terendah dari daerah Wini Kultivar merah. Fussarium sp adalah salah satu jenis cendawan gudang yang memilki kemampuan untuk menginfeksi benih pada waktu penyimpanan dan memiliki ketahanan hidup terhadap dingin dan kering (Justice \& Bass, 2002) sehingga menyebabkan kualitas benih menurun, perubahan warna benih, perkecambahan lambat, penyakit saat persemaian atau tanaman dewasa di lapangan. Selama masa penyimpanan benih, aktivitas cendawanpun terhenti karena syarat untuk pertumbuhannya tidak memadai (Rahayu, 1999). Cendawan Melanospora sp. secara makroskopis koloni dari cendawan ini berwarna putih dan pertumbuhan cendawan sangat cepat pada media PDA. Konidiofor berdinding halus, konidia berwarna coklat dan berbentuk bulat kasar. Cendawan ini paling banyak pada Kultivar putih dari daerah Wini $(75,56 \%)$, sedangkan daerah yang sama sekali tidak terserang cendawan ini adalah di Noemuti Kultivar merah dan Eban Kultivar hitam $(0,00$ $\%)$. Cendawan Collectotrichum sp. daat diklasifikasikan sebagi berikut, filum : mycota, kelas : deuteromycetes, ordo : melanconiales, famili : melanconiaceae, genus : colletotrichum, dan spesies : gloeosporioides (Alexopoulos et al., 1996). Berdasarkan hasil pengamatan terhadap cendawan ini bahwa hanya daerah Wini yang terserang, sedangkan daerah Noemuti dan Eban tidak terserang dengan prosentase $0,00 \%$.

Cendawan Aspergillus sp. merupakan salah satu jenis cendawan gudang yang memberikan banyak kerugian dan banyak menyerang benih pada saat penyimpanan (Justice dan Bass, 2002). Menurut Sutjiati\& Saenong (2002), bahwa cendawan Aspergillus sp. pada biji-bijian yang disimpan dapat menyebabkan penurunan daya kecambah, perubahan warna, kenaikan suhu, dan kelembapan didalam benih serta perubahan susunan kimia didalam benih produksi dan akumulasi mitotoksin pada benih. Cendawan ini juga menginfeksi benih kacang tunggak. Dari hasil pengamatan bahwa serangan cendawan Aspergillus sp. tertinggi pada daerah Eban dan Wini Kultivar hitam dan putih, sedangkan terendah pada daerah Noemuti Kultivar merah. Sedangkan serangan cendawan Altenaria sp.tertinggi pada Kultivar merah karena $100 \%$ mengalami serangan di daerah Wini dan Eban.

Hasil identifikasi cendawan pada benih kacang tunggak secara umum yang paling banyak terserang penyakit adalah daerah Wini dan Eban Kultivar merah. Penyakit yang disebabkan oleh beberapa cendawan diatas adalah bagian dari kegiatan pasca panen dan penyimpanan yang kurang memadai, kondisi lingkungan yang lembab sehingga menyebabkan peluang bagi cendawan untuk berkembangbiak. Dampak kerugian serangan cendawan pada benih dapat mempengaruhi daya tumbuh bahkan penurunan viabilitas benih (Tefa, 2015).

\section{Simpulan}

Berdasarkan penelitian yang telah dilaksanakan, maka dapat disimpulkan bahwa terdapat lima cendawan kontaminin yang mengkontaminasi benih kacang tunggak Kultivar merah, putih, hitam dari beberapa daerah di wilayah TTU yaitu Noemuti, Wini, dan Eban antara lain Cendawan Fussarium sp, Cendawan Melanospora sp, Cendawan Collectotrichum sp, Cendawan Aspergillus sp, dan Cendawan Altenaria sp. Dari beberapa cendawan patogen diatas, prosentase penyerangan tertinggi disebabkan oleh cendawan Fussarium sp.

\section{Pustaka}

Abadi A. L. 2003. Ilmu Penyakit Tumbuhan Ii. Bayumedia Puslitbang. Malang. Hal 132.

Alexopoulos, (1996) dan Gandjar, (1999), Introductory Mycolog Sons. New York.

Gomes K.A. Dan Gomes A.A. 1995. Prosedur Statistik Untuk Penelitian Pertanian. Edisi Ke 2. Jakarta : UI Press.

Inaizumi, H., B.B. singh, P.C. Sanginga, V.M. Manyong, A.A. Adesina, S.Tarawali. 1999. Adoption and inpact of dry-season dualpurpose cowpea in the semiarid zone of.

Justice, O.L., and L. N. Bass. 2002. Prinsip Dan Praktek Penyimpanan Benih. Jakarta : PT Rajda Persada.

Kamil, J. 1982. Teknologi Benih. Angkasa. Bandung

Manamgoda D. S, Rossman AY, Castlebury LA, Crous PW, Madrid H, ChukeatiroteE. 2014. The Genus Bipolaris. Stud Mycol. 79:221 288.

Misra, J.K; T.W; Mew \& S.D. Merca. 1994. Rice seed health and quarantine. In: Mew, T.W. dan Misra, J.K.(eds.). A manual of rice seed health testing. IRRI. Los banos, Laguna, philippines.

Ningsih, R., Mukarlina, dan R. Linda. 2012. Isolasi Dan Identifikasi Jamur dari Organ Bergejalah Sakit Pada Tanaman Jeruk Siam (Citrus nobilis var. microcarpa). Protobiont 1(1): 1-7.

Nugraheni, ES. 2010. Karakterisasi Biologi Isolat-Isolat Fussarium sp. pada Tanaman Cabai Merah (Capsicum аппиит L.) asal Boyolali. Skripsi. Jurusan Agronomi Fakultas Pertanian, Universitas 11 Maret, Surakarta. 57 hal (Dipublikasikan).

Parmeter JR. 1970. Rhizoctonia Solani : Biology and Pathology. California (US): Univ California Pr.

Putterill KM. 1954. Some graminicolous species of Helminthosporium and Curvulariaoccurring in south africa. Bothalia 6 (2) : 347-378.

Rahayu, (1999). Penyakit Tanaman Hutan Di Indonesia (Gejala Penyebab, dan Teknik Pengendaliaanya). Yogyakarta : Penerbit Kanisius.

Rusae, A., Tondok Et., Wiyono, S. 2015. Resiko Introduksi Gandum ke Timor Tengah Utara: Penyakit Hawar Daun Dan Busuk Batang. Tesis. Sekolah Pascasarjana. Institut Ertanian Bogor.

Roberts P. 1999. Rhizoctoniaforming fungi. 1th ed. Netherlands (NL) : CBS-

Sadikin Somaadmadja. 1990. Sumber Daya Nabati Asia Tenggara 1. Yogyakarta.

Sadjad, S. (1994). Kuantifikasi Metabolisme Benih. PT. Gramedia Widiasarana Indonesia, Jakarta. 145 hal

Sutopo L. 2004. Teknologi benih. Edisi revisi. Raja grafindo persada. Jakarta.

Semangun, H. 2000. Penyakit-Penyakit Tanaman Pangan Di Indonesia. Gadja Mada University Press. Yogyakarta.

Sutjiati, M. dan M.S. Saenong. (2002). Infeksi Cendawan Aspergillus Sp. Pada beberapa Kultivar / galur jagung hibrida umur dalam. Proseding Seminar Ilmiah dan Pertemuan Tahunan PEI, PFI, dan HPTI XV Sul-Sel. Maros, 29 Oktober (2002).

Toda T, Hayakawa T, Mghalu JM, Yaguchi S, Hyakumachi M. 2007. A new Rhizoctonia sp. Closely related to Waitea circinata causes a new disease of creeping bentgrass. J Gen Plant Pathol. 73:379-387.

Tefa, A. 2015. Pemanfaatan bakteri probiotik untuk menekan infeksi Colletotrichumocutatum dan meningkatkan mutu benih cabai (Capsicum апnиит L.) selama penyimpanan. Tesis. Sekolah Pascasarjana. Institut Pertanian Bogor. 